\title{
Perbaikan manajemen pakan dan pengolahan susu kambing PE di kelompok Peternak Muda Mandiri di Kabupaten Indragiri Hulu Riau
}

\author{
Evy Rossi ${ }^{*}$, Fajar Restuhadi $\$$, \& Akhmad Ibrahim R. S. Hasibuan \\ Fakultas Pertanian, Universitas Riau \\ * evy.rossi@lecturer.unri.ac.id
}

\begin{abstract}
Abstrak. Kegiatan ini bertujuan untuk a) meningkatkan kemampuan peternak dalam manajemen pakan dan pemerahan susu dan b) meningkatkan kemampuan inovasi peternak dalam mengembangkan diversifikasi susu segar menjadi pangan fungsional. Metode pelaksanaan dilakukan dengan penyuluhan dan demonstrasi plot tentang manajemen pakan tentang pemanfaatan daun dan pelepah sawit dijadikan pakan komplit yang diformulasikan dengan menggunakan bahan-bahan pakan berupa limbah pertanian atau industri pertanian lainnya. Berdasarkan hasil pengamatan selama demplot dibandingkan dengan ternak kambing PE yang dipelihara secara semi intensif terhadap rataan tingkat konsumsi ransum dan pertambahan bobot badan ternak kambing PE yang mendapat ransum komplit berbentuk pellet ransum berbentuk pellet (615.50 g/ekor/hari) lebih tinggi dari pada tingkat konsumsi ternak(566.50 g/ekor/hari) yang dipelihara peternak secara semi intensif. Pertambahan bobot badan ternak demplot adalah $193.50 \mathrm{~g} / \mathrm{ekor} / \mathrm{hari}$ lebih tinggi daripada pertambahan bobot badan ternak yg dipelihara peternak ( $54.90 \mathrm{~g} / \mathrm{ekor} / \mathrm{hari})$. Pengenalan dan praktek pengolahan susu menjadi pangan fungsional telah dilakukan dengan mengolah susu menjadi minuman fermentasi berupa yoghurt dan kefir serta produk turunannya. Dari kegiatan ini dapat disimpulkan bahwa dengan perbaikan manajemen pakan dan pemenuhan kebutuhan ternak produksi susu bias meningkat. Peningkatan Iptek peternak berdampak positif terhadap orientasi beternak kambing PE bukan hanya sekedar tabungan tetapi juga sebagai penghasil susu yang secara ekonomis sangat tinggi nilainya.
\end{abstract}

Kata Kunci: peranakan etawah, pakan, susu, yoghurt, kefir

\begin{abstract}
The objectives of community service were to) improve the ability of Etawah breed goat breeders (PE) in feed management and milking and b) increase the ability of farmers to innovate in developing the diversification of fresh milk into functional food. The method of implementation was carried out by extension and demonstration plots on feed management by utilizing palm leaves to be used as a complete feed ingredient formulated using other feed ingredients such as agricultural waste or other agricultural industries.Based on observations during the demonstration plot it was compared with PE goats that were kept semi-intensively on the average level of ration consumption and body weight gain per day. The average body weight gain of PE goats receiving a complete ration in the form of pellets $(615.50 \mathrm{~g} /$ head / day) is higher than the consumption rate of livestock ( $566.50 \mathrm{~g} /$ head / day) which were kept by breeders semiintensively. The body weight gain of the demonstration plot cattle was $193.50 \mathrm{~g} / \mathrm{head} /$ day which was higher than the body weight gain of PE goats kept by breeders (54.90 g/head/day). The introduction and practice of processing milk into functional food had been carried out by processing milk into fermented drinks in the form of yogurt and kefir and their derivative products. From this activity, it can be concluded that by improving feed management and meeting the needs of livestock, milk production can increase. The improvement of farmer science and technology had a positive impact on the orientation of raising PE goats not only for savings but also as a producer of milk which was economically very high in value.
\end{abstract}

Keywords: etawah, ration, milk, yoghurt, kefir

To cite this article: Rossi, E., F. Restuhadi., \& A. I. R. S. Hasibuan. 2020. Perbaikan manajemen pakan dan pengolahan susu kambing PE di kelompok Peternak Muda Mandiri di Kabupaten Indragiri Hulu Riau. Unri Conference Series: Community Engagement 2: 464-470. https://doi.org/10.31258/unricsce.2.464-470

(C) 2020 Authors

Peer-review under responsibility of the organizing committee of Seminar Nasional Pemberdayaan Masyarakat 2020 


\section{PENDAHULUAN}

Di Kabupaten Indragiri Hulu, Provinsi Riau, terdapat sejumlah peternak yang memelihara ternak kambing secara tradisional dan semi-intensif dan sebagian besar memelihara kambing lokal yaitu kambing kacang dan kambing peranakan etawah (PE). Keunggulan dari kambing PE ini adalah kemampuan gandanya sebagai penghasil susu dan daging (Astuti et al. 2012). Dari beberapa kelompok peternak tersebut, terdapat kelompok peternakan yang sudah memelihara kambing PE secara semi intensif dan memiliki kandang komunal yaitu Kelompok Peternak Kambing Muda Mandiri

Kelompok ini terletak di Kecamatan Lubuk Batu Jaya, Indragiri Hulu. Anggota kelompok ini telah menjadikan usaha budidaya kambing PE dengan output utama bibit kambing PE sebagai kegiatan ekonomi yang sudah dapat dikategorikan sebagai unit Usaha Mikro, Kecil, dan Menengah (UMKM). Kelompok ternak kambing Muda Mandiri yang beranggotakan 10 orang peternak terbentuk semenjak tahun 2011 yang berawal dari program sarjana membangun desa (SMD). Usaha kelompok ini berorientasi pada pengembangan ternak kambing PE dengan tujuan utama menghasilkan bibit kambing PE. Populasi kambing kelompok Muda mandiri sekarang berjumlah 43 ekor yang terdiri atas induk 17 ekor, jantan 4 ekor dan 22 ekor anak yang dipelihara secara komunal.

Selain mempunyai kandang komunal, sebagian anggota ini juga memiliki kandang sendiri. Kambingkambing ini telah mampu beradaptasi baik dengan lingkungan Kabupaten Indragiri Hulu. Peralatan dan fasilitas yang mendukung usaha ini antara lain alat pencacah hijauan makanan ternak, mixer, alat pembuat pelet pakan ternak, oven, genset, dan gudang. Ketidakcukupan asupan nutrisi diketahui merupakan salah satu penyebab rendahnya produksi susu.

Pasca bencana kebakaran hutan disekitar usaha peternakan ini, menimbulkan permasalahan pada peternak. Permasalahan-permasalahan yang saat ini dihadapi oleh kedua kelompok peternak ini adalah dampak akibat bencana asap yang diderita oleh peternak sejak dua tahun terakhir ini. Dampak langsung yang dirasakan oleh ternak adalah ketersediaan bahan pakan. Fungsi pakan bagi ternak adalah untuk mempertahankan kehidupannya, pertumbuhan dan produksi berupa daging dan susu serta untuk reproduksi. Oleh karena itu kebutuhan ternak akan pakan harus dipenuhi sesuai dengan tingkat pertumbuhannya, agar produktivitas ternak untuk menghasilkan daging atau susu menjadi optimal (Adriani et al. 2014), selain itu ternak juga dapat memiliki hasil sampingan berupa pupuk cair ataupun pupuk padat (Novra et al. 2019).

Permasalahan-permasalahan yang sekarang dihadapi adalah 1) rendahnya produktivitas ternak akibat dampak kabut asap tersebut angka konsepsi dan kelahiran ternak sangat rendah, 2) kurangnya pengetahuan peternak akan manajemen pakan. 3) Turunnya motivasi peternak untuk ternak penghasil susu, 4). Kurangnya dan rendahnya pengetahuan tentang teknologi pemerahan dan pengolahan susu segar. Pada saat setiap kelahiran anak, peternak belum berani memerah susunya untuk komersil, sebagian besar susunya hanya dikonsumsi oleh anak dan sebagian lagi diperah untuk konsumsi internal.

Berdasarkan hal tersebut di atas kegiatan pengabdian kepada masyarakat yang dilakukan adalah perbaikan manajemen pakan dengan mengintroduksi formulasi ransum dan replacement milk serta, teknologi pemerahan susu dan diversifikasi pengolahan susu kambing sehingga masa simpan susu bisa diperpanjang. Susu kambing yang diproduksi setiap hari walaupun masih rendah tetapi dapat meningkatkan pendapatan peternak, yaitu dijual dalam bentuk segar dan susu diolah menjadi susu pasteurisasi atau difermentasi menjadi minuman fungsional seperti yoghurt (Bonnifait et al., 2009) atau kefir (Michael and Sherman 2009). Yoghurt merupakan produk olahan dari susu segar dengan bantuan bakteri asam laktat (Tamime and Robinson 2007). Bakteri ini berperan dalam pembentukan asam laktat hasil melalui reaksi glikolisis (Nelson and Cox 2005). Yoghurt ini dapat dikonsumsi oleh orang yang tidak mampu minum susu karena tiadanya enzim laktase yang umum disebut sebagai lactose intolerance (Michael and Sherman 2009). Bakteri yang umum digunakan dalam pembuatan yoghurt adalah Lactobacillus delbrueckii subsp. bulgaricus dan Streptococcus salivarius subsp. thermophilus sebagai bakteri starternya dan bakteri-bakteri lain yang bersifat probiotik (Rossi et al., 2018).

Minuman fermentasi lainnya yang dibuat dari susu fermentasi adalah kefir. Kefir dapat dibuat dari susu sapi, kambing, sari kedelai atau kombinasi dari berbagai susu (Rossi et al., 2016). Kefir merupakan salah susu fermentasi yang menggunakan BAL dan ragi yang bersimbiotik dalam bentuk Kefir grain (Leite et al., 2015). Kefir memiliki rasa, warna dan konsistensi yang menyerupai yoghurt dan memiliki aroma khas yeasty (seperti tape). Kelebihan kefir adalah terdapatnya bakteri probiotik yang menghasilkan zat-zat metabolit primer dan sekunder yang dibutuhkan dan dapat menghambat pertumbuhan bakteri patogen di dalam saluran pencernaan (Liong 2011). 
Permasalahan utama pada kelompok ternak ini adalah rendahnya produktivitas susu kambing, karena belum diterapkannya manajemen pakan yang baik. Kondisi tersebut disebabkan karena peternak belum mengoptimalkan pemanfaatan sumberdaya yang mereka miliki dan belum memberikan ternak ransum sesuai dengan kebutuhan ternak. Untuk mengatasi permasalahan ini, diupayakan untuk meningkatkan IPTEK peternak tentang manajemen pakan dan formulasi ransum, sehingga melalui kegiatan ini diperoleh formulasi ransum sesuai dengan kebutuhan ternak, sehingga produksi susu meningkat dan bisa dipasarkan mengingat peluang pasar untuk susu kambing murni masih terbuka luas.

Tujuan kegiatan pengabdian kepada masyarakat pada kelompok ini adalah untuk 1) memperbaiki dan menerapkan manajemen pakan yang benar sehingga kebutuhan ternak terpenuhi, sesuai dengan tingkat produksi ternak. 2) membuat ransum komplit yang berbahan baku dari limbah perkebunan dan pertanian, 3) meningkatkan iptek pertenak dalam pengolahan susu sebagai minuman fungsional.

\section{METODE PENERAPAN}

Metode pelaksanaan untuk menyelesaikan permasalahan mitra adalah transfer ilmu dan teknologi melalui penyuluhan, demonstrasi dan pembimbingan. Materi penyuluhan adalah tentang konsep manajemen pemeliharaan ternak kambing perah, manajemen produksi dan penanganan susu, teknologi pengolahan susu untuk memperpanjang masa simpan, dan introduksi manajemen pemasaran. Demonstrasi teknologi yang ditransfer terdiri dari: formulasi ransum dan pemberian ransum yang benar, pemberian susu pengganti untuk anak kambing, dan diversifikasi pengolahan susu kambing

Pelaksanaan kegiatan dilakukan menggunakan beberapa cara yaitu:

a. Penyuluhan

Penyuluhan merupakan cara yang paling tepat dalam memberikan pengetahuan kepada peternak. Untuk memantapkan pelaksanaan kegiatan dan hasil penyuluhan, maka brosur tentang materi yang akan disampaikan didistribusikan kepada peserta pelatihan.

b. Pelatihan dan Percontohan

Memperagakan/mempercontohkan dalam memformulasikan dan pembuatan ransum, memerah susu, penangan susu pasca panen, pembuatan es krim, es mambo dan susu fermentasi (yoghurt dan kefir).

c. Bimbingan dan Pembinaan

Peternak yang telah mulai menerapkan Iptek yang ditransfer akan dibimbing dengan pembinaan yang dilakukan secara periodik melalui koordinasi dengan ketua kelompok.

d. Diskusi dan Konsultasi

Pada saat penyuluhan, pelatihan/percontohan dan pembinaan, selalu diadakan diskusi dan konsultasi untuk lebih memantapkan kegiatan pengabdian masyarakat yang dilaksanakan.

e. Evaluasi dan Monitoring

Evaluasi kegiatan ini dilakukan dalam beberapa tahap, yaitu: 1) sebelum kegiatan yang bertujuan untuk mengetahui pengetahuan peternak tentang teknologi yang akan ditransfer. 2) Saat kegiatan sedang berjalan,evaluasi dilakukan untuk mengetahui minat peternak terhadap kegiatan yang dilaksanakan dan kemampuan peternak dalam menyerap materi yang diberikan. 3) setelah kegiatan dilaksanakan, untuk mengetahui pengetahuan peternak tentang teknologi yang diaplikasikan.

\section{HASIL DAN KETERCAPAIAN SASARAN}

\section{Perbaikan Manajemen Pakan}

Pelaksanaan kegiatan di kelompok peternak ini lebih banyak difokuskan pada manajemen pemberian pakan. Hal ini dilakukan karena Mitra ini mengalami penurunan populasi ternak yang sangat drastis dibandingkan dari jumlah populasi ternak tahun yang lalu. Kondisi ini disebabkan kedua lokasi usaha peternakan terletak di sekitar area yang terjadi kebakaran lahan di Provinsi Riau. Akibat penyusutan populasi ternak akibat dampak kebakaran lahan menyebabkan rasio ternak jantan dan betina tidak seimbang lagi. Perbaikan manajemen pemberian pakan ini diharapkan akan memberikan dampak positif terhadap peningkatan populasi ternak. Peningkatan populasi ternak akan seiring dengan produksi susu yang selanjutnya diolah menjadi produk yang bernilai ekonomis.

Pada tahapan pengenalan teknologi pembuatan ransum komplit yang berbahan dasar limbah pertanian dilakukan dengan beberapa metode: antara lain: Penyuluhan, praktek dan membuat demonstrasi plot. Penyuluhan yang dilakukan adalah tentang pengetahuan bahan pakan, menentukan kebutuhan ternak akan 
membuat formulasi ransum sesuai dengan kebutuhan ternak. Pada penyuluhan ini pembuatan ransum berbentuk pellet.

Produktivitas ternak yang rendah disebabkan karena kambing belum mendapatkan asupan nutrisi yang cukup baik kualitas maupun kuantitasnya. Hal ini disebabkan pemberian ransum pada ternak belum disesuaikan dengan kebutuhannya. Kebutuhan ternak akan zat nutrisi sangat tergantung pada jenis kelamin, umur, bobot, dan tingkat produksi (Mathius et al. n.d.) Pada kegiatan ini peternak diberikan pengetahuan tentang menentukan kebutuhan ternak akan nutrisi, pengenalan bahan pakan dan memformulasikan ransum sesuai dengan tingkat produksi dan kebutuhan ternak. Pemilihan bahan baku yang digunakan dalam formulasi mempertimbangkan keberlangsungan ketersediaan secara lokal, pertimbangan harga/unit nutrien, batasan penggunaan dan kemudahan dalam pencampuran.

Aplikasi penggunaan ransum komplit dilakukan melalui beberapa tahapan yaitu: a) Pembuatan formulasi ransum standar, b) Produksi ransum komplit c) Pemberian aplikasi ransum komplit pellet pada peternak Mitra UMKM dengan membuat demonstrasi plot. Proses pembuatan ransum komplit dapat dilihat pada Gambar 1 .
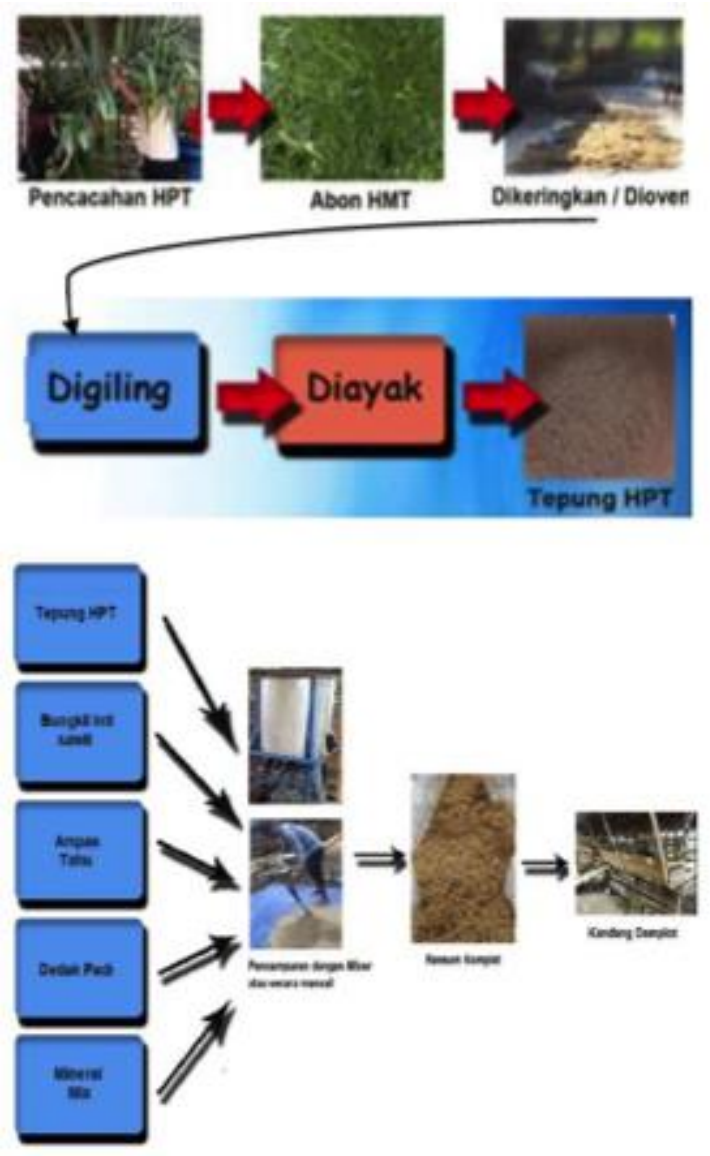

Gambar 1. Proses pembuatan ransum komplit untuk kambing PE

Setelah ransum komplit dibuat, selanjutnya dilakukan demonstrasi plot yang mana delapan ekor ternak kambing dara dipelihara secara intensif pada kandang (Gambar 2) dan dikelompokan menjadi dua kelompok. Kelompok I ternak diberikan ransum berupa ampas tahu kira $0,5 \mathrm{~kg} / \mathrm{ekor} / \mathrm{hari}$ dan daun kacang atau limbah pertanian yang ada disekitar peternakan dicampur dengan rumput lapangan. Makanan kasar ini diberikan secara adlibitum. Pada kelompok II ternak diberi ransum komplit dengan kandungan protein kasar $(\mathrm{PK})+$ 13\% dan TDN 63\%. Bahan kering (BK) ransum diberikan sebanyak 1\% dari bobot badan ternak yang ditimbang sebelumnya (Gambar 2) dan pemberiannya dua kali sehari yaitu pagi dan sore hari.

Berdasarkan hasil pengamatan selama demplot dibandingkan dengan ternak kambing PE yang dipelihara secara semi intensif terhadap rataan tingkat konsumsi ransum dan pertambahan bobot badan ternak kambing PE yang mendapat ransum komplit berbentuk pellet dapat dilihat pada Tabel 1. Berdasarkan Tabel 1 terlihat 
bahwa tingkat konsumsi kambing PE yang mendapat ransum berbentuk pellet (615.50 g/ekor/hari) lebih tinggi dari pada tingkat konsumsi ternak (566.50 gr/ekor/hari) yang dipelihara peternak secara semi intensif. Hal ini disebabkan ternak kambing yang mendapat ransum pellet tidak memiliki kesempatan untuk menyeleksi pakan dan pada ransum pelet ini, hijauan pakan ternak berupa limbah pertanian sebagai sumber serat telah memiliki partikel yang relatif kecil. Ukuran partikel yang relatif kecil menyebabkan ternak mudah mencerna sehingga laju makanan di dalam saluran pencernaan relatif singkat. Kondisi ini menyebabkan tingkat konsumsi meningkat. Meningkatnya tingkat konsumsi ransum diikuti dengan meningkatnya bahan kering ransum, hal ini disebabkan ransum berbentuk pellet mengandung kadar air relatif lebih rendah. Rendahnya kadar air ransum berbentuk pellet secara langsung menyebabkan tingkat konsumsi BK ransum menjadi tinggi

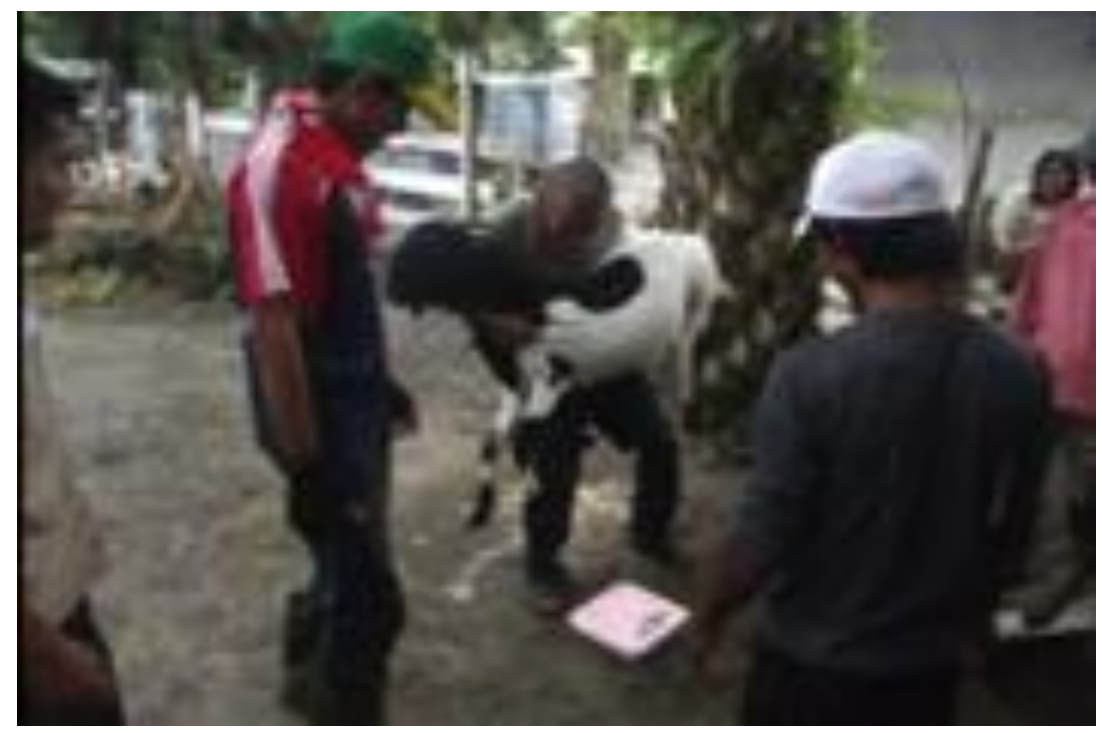

Gambar 2. Penimbangan ternak

Pertambahan bobot badan ternak demplot adalah $193.50 \mathrm{gr} / \mathrm{ekor} / \mathrm{hari}$ lebih tinggi daripada pertambahan bobot badan ternak yang dipelihara peternak (54.90gr/ekor/hari). Hal ini disebabkan oleh tingkat konsumsi BK ransum ternak demplot lebih tinggi. Rerata pertambahan bobot badan kambing PE dapat dilihat pada Tabel 1

Tabel 1. Rerata hasil pengamatan di Demplot peternakan kambing PE di Kelompok Peternak Muda Mandiri

\begin{tabular}{lcc}
\multicolumn{1}{c}{ Pengamatan } & Semi Intensiv Kelompok I & Intensiv Kelompok II \\
\hline Konsumsi ransum (gr/ekor/hr) & 566.50 & 615.50 \\
Konsumsi BK ransum (gr/ekor/hr) & 234.00 & 406.00 \\
Pertambahan bobot badan (gr/ekor/hr) & 54.90 & 193.50 \\
\hline
\end{tabular}

Meningkatnya tingkat konsumsi ransum diikuti dengan meningkatnya bahan kering ransum, hal ini disebabkan ransum berbentuk pellet mengandung kadar air relatif lebih rendah. Rendahnya kadar air ransum berbentuk pellet secara langsung menyebabkan tingkat konsumsi BK ransum menjadi tinggi. Pertambahan bobot badan ternak demplot adalah $193.50 \mathrm{gr} / \mathrm{ekor} / \mathrm{hari}$ lebih tinggi daripada pertambahan bobot badan ternak yg dipelihara peternak (54.90 gr/ekor/hari). Hal ini disebabkan oleh tingkat konsumsi BK ransum ternak demplot lebih tinggi. Pertambahan bobot badan merupakan pertambahan bobot massa akibat terjadinya biosintesis makro nutrien di dalam tubuh ternak.

\section{Manajemen Pemerahan Susu}

Pemerahaan susu kambing pada UMKM ini belum dilakukan secara rutin. Pada kelompok peternak Muda Mandiri sudah mulai dilakukan pemerahan susu kambing tapi, belum dilakukan secara rutin. Hal ini disebabkan peternak belum menjadikan susu kambing ini sebagai komoditi yang mempunyai nilai ekonomis. 
Pemerahan hanya dilakukan kalau mereka ingin minum susu kambing jika ada keluarga anggota membutuhkan karena ada gangguan kesehatan, seperti stamina lemah ataupun ada yang sakit.

Pada menjelang berakhir kegiatan ini 3 ekor induk kambing hampir mendekati masa kering dan satu ekor induk laktasi dengan produksi 0,6-08 1/ekor/hari. Produksi susu masih bisa ditingkatkan jika konsumsi pakan ternak bias ditingkatkan. Menurut Sodiq dan Abidin) kambing PE bias menghasilkan susu setiap harinya sekitar 0,45-1,0 I (Sodiq and Abidin 2008). Relatif tingginya produksi susu pada ternak di kelompok muda mandiri disebabkan oleh induk kambing ini sudah biasa susunya diperah dan pemerahan susu pada periode ini adalah periode laktasi yang ketiga kalinya. Diharapkan di akhir tahun ini terdapat tujuh ekor ternak laktasi masing-masing empat ekor laktasi pada kelompok peternak Sehat dan 3 ekor laktasi pada kelompok peternak Muda Mandiri.

\section{Pengolahan Pangan Fungsional Berbasis Susu}

Pangan fungsional adalah produk pangan yang mempunyai fungsi fisiologis dan berkhasiat bagi kesehatan manajemen mikroflora usus dapat mengurangi resiko kena penyakit degeneratif. Salah satu produk pangan fungsional adalah susu fermentasi, seperti yoghurt, yakult, koumis, maupun kefir. Kefir adalah pangan fungsional probiotik, terbuat dari susu yang difermentasi dengan granula kefir dan mengandung sekitar 40 jenis bakteri menguntungkan (beneficial bacteria) serta ragi (yeast).

Penyuluhan dan praktek penanganan dan pengolahan susu kambing (Gambar 3) dilaksanakan lokasi di lokasi peternakan kambing PE Muda Mandiri, Sungai Lalak Indragiri Hulu. Pada penyuluhan dan praktek pengolahan susu disampaikan materi-materi berupa penanganan susu, pembuatan yoghurt, soyghurt, es mambo dan es krim dari susu, yoghurt dan kefir serta pengolahan kefir untuk kosmetik berupa masker kefir (Gambar 4).

Melalui kegiatan ini anggota kelompok mitra mendapat bantuan pengadaan untuk pengolahan dan penyimpanan susu seperti termometer, blender dan Freezer. Diharapkan dengan meningkatnya populasi ternak akan diikuti dengan banyaknya induk laktasi sehingga produksi susu akan meningkat.

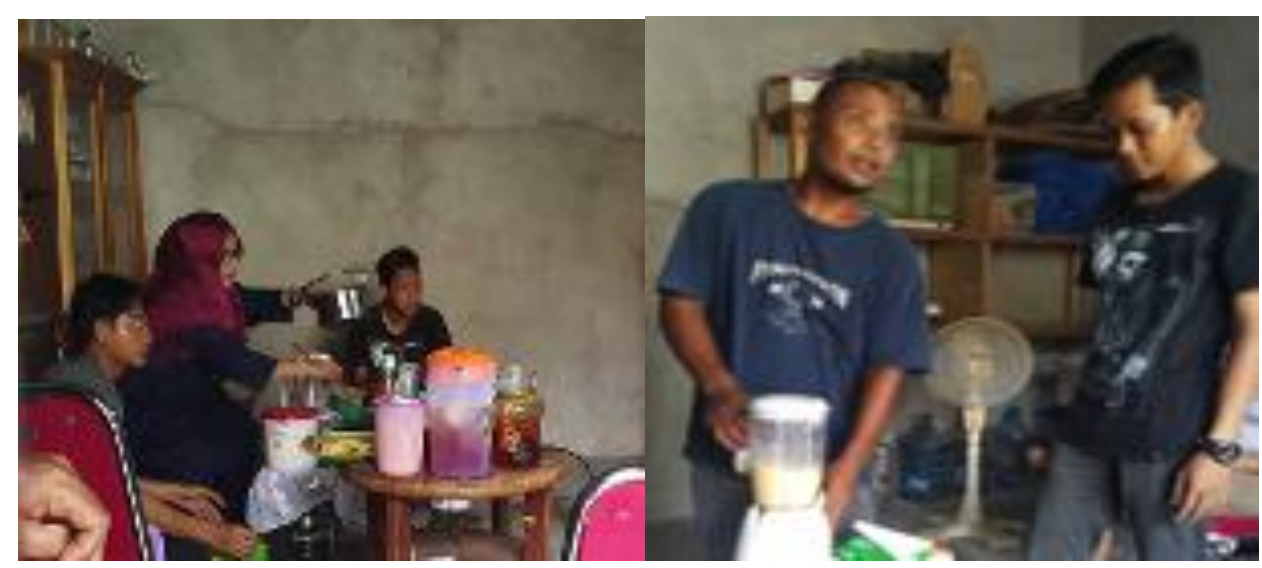

Gambar 3. Praktek pengolahan susu menjadi pangan fungsional

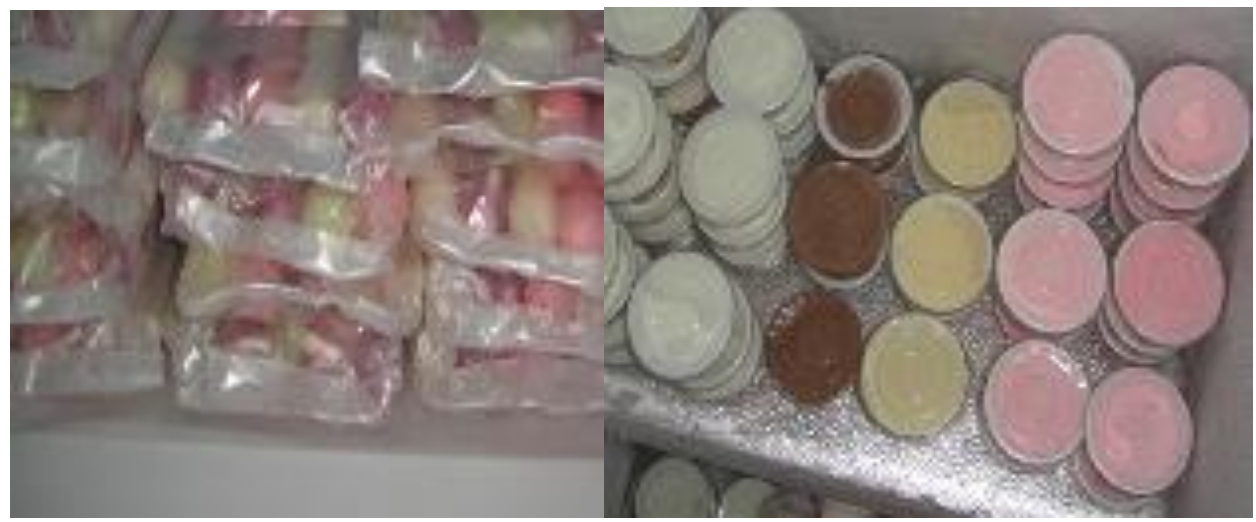

Gambar 4. Pangan fungsional berupa Es mambo Kefir dan es krim yoghurt 


\section{KESIMPULAN}

Kondisi lingkungan sangat menentukan produktivitas ternak, lingkungan yang tidak sehat akibat polusi sangat menentukan status kesehatan ternak. Kondisi ternak yang kurang baik akan dapat ditingkatkan dengan manajemen pemeliharaan dan pemberian pakan yang sesuai dengan kebutuhan ternak. Pakan ternak dapat dibuat dari limbah yang ada disekitar peternak dengan memperhatikan formulasi bahan pakan untuk memenuhi kebutuhan gizi ternak. Informasi dan aplikasi Iptek petani/peternak di daerah terpencil sangat dibutuhkan untuk meningkatkan potensi atau aset yang dimilikinya. Melalui kegiatan kegiatan ini mitra baru menyadari bahwa susu kambing PE merupakan komoditi yang sangat bernilai ekonomis apabila dikelola dengan benar dan tepat.

\section{UCAPAN TERIMA KASIH}

Ucapan terimakasih disampaikan kepada Direktorat Riset dan Pengabdian Kepada Masyarakat Kemenristekdikti dan Lembaga Penelitian dan Pengabdian kepada Masyarakat Universitas Riau yang telah membiayai kegiatan ini melalui Program Iptek bagi Masyarakat. Ucapan terimakasih juga disampaikan kepada semua pihak yang membantu pelaksanaan kegiatan ini.

\section{DAFTAR PUSTAKA}

Adriani, A., A. Latif, and S. Fachri. 2014. Peningkatan Produksi Dan Kualitas Susu Kambing Peranakan Etawah Sebagai Respon Perbaikan Kualitas Pakan. Jurnal Ilmiah Ilmu-Ilmu Peternakan, 17(1), 15-21. https://onlinejournal.unja.ac.id/jiip/article/view/2087

Astuti, D. A., A. Sudarman, and J. R. Darmaga. 2012. Dairy goats in Indonesia: Potential, opportunities and challenges. In First Asia Dairy Goat Conference, 9, 47.

Bonifait, L., F. Chandad, and D. G. Dental. 2009. Probiotics for Oral Health: Myth or Reality? Journal of the Canadian, 75(8), 585-590. https://www.renuzoral.com/wp-content/uploads/2016/05/585.pdf

Leite, A.M.O., M.A.L. Miguel, and R.S. Peixoto. 2015. Probiotic Potential of Selected Lactic Acid Bacteria Strains Isolated from Brazilian Kefir Grains. Journal of Dairy. http://www.sciencedirect.com/science/article/pii/S0022030215002295.

Liong, M. T. 2011. Probiotics Biology Genetics and Health Aspects. Edited by Min Tze Liong. Springer US.

Mathius, I.W., I.B. Gaga, and I.K. Sutama. 2002. Kebutuhan Kambing PE Jantan Muda Akan Energi Dan Protein Kasar: Konsumsi, Kecernaan, Ketersediaan Dan Pemanfaatan Nutrien. Balitnak.Litbang.Pertanian.Go.Id. Accessed October 11, 2020. http://balitnak.litbang.pertanian.go.id/phocadownload/JITV/99-109.pdf.

Michail, S. and P. M. Sherman. 2009. Probiotics in Pediatric Medicine. Edited by S Michail and P. M. Sherman. NJ. USA: Humana Press, a part of Springer Science + Business Media, LLC.

Nelson, D. L. and Michael M Cox. 2005. Principles of Biochemistry. 4th ed. New York.

Novra, A., A.Adriani, S Suparjo, and N. Nelson. 2019. Penguatan Usaha Kelompok Peternak Pelaku Integrasi SawitSapi Berbasis Limbah Di Kecamatan Mestong. Riau Journal of Empowerment, 2(2), 43-54. https://doi.org/10.31258/raje.2.2.43-54.

Rossi, E., E. Roza, Y. Sofyan, S.N. Aritonang, and E. Purwati. 2018. Characterization of Probiotics Properties of Lactobacillus from Solid Waste of SoyMilk Production. Asian Journal of Microbiology, Biotechnology and Environment. http://www.envirobiotechjournals.com/article_abstract.php?aid=8962\&iid=260\&jid=1.

Rossi, E, F. Hamzah, and Febriyani. 2016. The Proportion of Goats' Milk and Soya Milk in Kefir Production Process. Jurnal Peternakan Indonesia, 18(1), 13-20. http://jpi.faterna.unand.ac.id/index.php/jpi/article/view/238.

Sodiq, I.A. and I.Z. Abidin. 2008. Meningkatkan Produksi Susu Kambing Peranakan Etawah. Jakarta: Agro Media Pustaka.

https://books.google.com/books?hl=en\&lr=\&id=vBwE2JRSJNUC\&oi=fnd\&pg=PR3\&dq=produksi+susu+kamb ing+Peranakan+Etawah\&ots=wnUN8o-kjB\&sig=ht3jWnwFtsV0WHdjSa1x9xqSHDc.

Tamime, A. and R. Robinson. 2007. Yogurt, Science and Technology. Cambridge England: Woodhead Publishing Limited, Abington Hall, Abington. 